\title{
On The Protection of College Students' Rights and Interests in The "Gig Economy"
}

\author{
Ying-jue Du 1,a, Hong-zhen Lin1,b, ${ }^{\text {, }}$, Sen Yang 1,c,and Gui-dan Xu1,d \\ 1School of Hengda Management, Wuhan University of Science and Technology Wuhan, China \\ 1Distinct addresses: 947 He Ping Street, Hubei Wuhan 430081, China
}

\begin{abstract}
The purpose of this paper is to study the issues related to students' rights and interests in the gig economy and how to strengthen the rights and interests of students in the gig economy. By means of questionnaire survey and interview, this paper conducts literature research and makes an in-depth analysis of the phenomenon that the rights and interests of college students are infringed under the new employment mode, including labor security, social welfare and wage security. The main reasons for the serious infringement on the rights and interests of college students are weak legal awareness of college students, inadequate supervision of the platform and unclear legal definition. This paper puts forward a series of improvement measures on the basis of analyzing the current situation of the gig economy of college students. The conclusion is that under gig economy, the protection of rights and interests college students also need to be implemented from the legal level, and we should build college students rights and interests guarantee system, improve school social and related departments for rights and interests of awareness among college students, and enhance their rights and interests of security and risk prevention awareness, then effectively protect their economic rights and interests.
\end{abstract}

Keywords-Gig Economy; College Students; Rights And Interests; Protection

\section{INTRODUCTION}

In recent years, under the influence of China's supply-side structural reform, the sharing economy has achieved highspeed growth, According to the annual report on China's shared economic development, the number of active employees in the sharing economy in China in 2017 was about 7.16 million, representing $9.7 \%$ of the new employment in towns and 1.31 million, compared with 2016, and the number of people participating in the sharing economy in 2017 was more than 700 million, It is about 100 million more than in 2016. A good economic posture provides employment opportunities for more people, addressing overcapacity and idle labour. The gig economy which is a new type of employment model, the optimal allocation of human resources, the employment of people and enterprises to form a non-contractual labor relations, is no longer a strange word for many businesses and job seekers, and, like the sharing economy, has gradually developed a situation. Through this new type of employment model, workers can share their labor, knowledge, skills and so on to quickly get paid [1]

\section{CURRENT SITUATION OF COLLEGE STUDENTS' GIG ECONOMY}

At present, there are two reasons why the employment pattern of gig economy jobs is favored by the market: from the point of view of enterprises, the old employment model has not been able to meet the needs of enterprise production and operation. The emergence of gig economy can save the human resources cost of enterprises. From the point of view of gig economy workers, the current active in the labor market are no longer pursue the traditional nine-night five work mode. They pursue challenging and varied ways of working, so the emergence of the gig economy gives them new pursuits in their lives to live in.

Some scholars have done a survey on the current situation of gig economy-part college students in the Xiaogan region of Hubei Province. In the type of gig economy-duty activities, college students can choose the industry is also a variety of, the hottest industry is tutoring, followed by waiters, guides and other industries. Analysis by the results of the survey found that most students will not be fixed to a certain type of occupation, often try a number of different gig economy-part activities. In addition, in terms of working hours, more than half of college students prefer to choose hours or weekend work. Therefore, it can be concluded that college students prefer a high degree of freedom, flexibility of the gig economy job occupation [2]. There are many reasons for college students to join the gig economy group, but most of them are mainly economic factors and time factors. On the one hand can obtain independent economic income, on the other hand, can make their skills in society to get exercise.

\section{The Main Problems Of College Students ' Rights AND INTERESTS IN THE GIG ECONOMY}

There is no doubt that we inevitably have to accept the challenges and risks it brings to us, while enjoying the benefits of the gig economy-jobs. The survey shows that college students often encounter the following problems in their gig economy-part activities: 


\section{A. Firstly, The Issue Of Labor Safety And Security}

According to the survey, in the gig economy-part activities that college students dabble in, the takeaway industry is more likely to encounter accidents than other industries.

It is understood that many takeaway platforms are now implementing crowd sourcing services. For college students, crowd sourcing forms of gig economy-work activities are more attractive than traditional part-time jobs [3].

In the first half of 2017, the Shanghai takeaway industry occurred a total of 76 traffic safety casualties, several riders in the delivery process was hit and killed. and college students as the main force of the takeaway industry, their security issues are worthy of attention. There is a case: a college student for work-study, unexpectedly expose to the delivery of a safety accident on the way, not only their own compensation of 70,000 yuan, but also by the company dismissal. The college student has been defending his rights. However, after consulting many parties, the result is that "school students and employers are not part of the labor relationship, so they can only go to court to sue."

There are laws and regulations "school students use their spare time to work out, not as employment, without establishing labor relations, and may not sign labor contracts." This means that college students not in the scope of labor law protection. But college students in the process of gig economy jobs encountered problems can be divided into the category of civil disputes. In civil employment relations, the rights and obligations of both parties are equal, and agreements signed between college students and enterprises may be regarded as contracts for the exchange of labor services for remuneration and should be protected by contract law [4].

At present, under the existing legal regulations, the common work-related injury relief methods for college students are mainly solved through civil tort damages. From the analysis of employer's responsibility and employee responsibility, first of all, when the employer has the fault of subjective factors in the accident, it is necessary to bear the liability. The scope and extent of the employer's liability depends on subjective factors. Often this point of evaluation of the standard is the employer to decide, so the employing unit can often reduce or even dispense with the corresponding liability for injury compensation. Secondly, because the workrelated injury insurance belongs to the compulsory insurance, the employing unit generally does not directly bear the liability. Moreover, compared with the work-related injury insurance, tort liability compensation is more cumbersome in procedure, so it will be very difficult for college students to get the corresponding damages [5].

\section{B. Secondly, the Issue Of Social Security Benefits}

Social insurance is a means of relief that workers can provide the necessary help when they are exposed to labor risks. However, the resolution of social security and social welfare problems is still in a blank stage in the gig economy-work, it is understood that most shared platforms have a great problem of social security loopholes. Even drip taxi, OFO, mobike such a well-known platform, are plagued by social security problems. Many university students engaged in the economic activities of gig economy jobs are equivalent to a part-time non-contract employee, and there are some clear definitions of part-time employment in the 2003 opinion of the Ministry of Labour and Social Security on a number of issues relating to part-time employment. Employees engaged in part-time work may establish labour relations with one or more labour units. It is clear that this "non-staff" treatment is significantly lower than that of welfare and regular staff. And many contracts on the network platform generally rarely involve part-time employees of the work-related injury insurance system or safety and security issues, some even almost no [6].

Under such circumstances, the employment relationship of college students in the labor market cannot be determined, China's employing units, workers and the country's Trinity Social security system cannot solve this flexible employment model of the predicament [7].

\section{Thirdly, the Issue Of Wage Security}

The issue of pay is also another topic closely related to gig economy-wage college students. The results of the survey showed that more than half of the respondents had been subjected to wage injustice, the main violations of the wages and interests were: the employer did not pay wages on time; there was no justification for the deduction of wages; the actual wages were not in accordance with the original agreed standards; and forced overtime was not matched by overtime pay. From this, it can be seen that college students suffer from the impact of wage rights and interests and many, the status quo of college students' wage rights and interests is not optimistic [8].

In the opinions on improving the teaching quality of higher vocational education in an all-round way, the contents of the mode of cooperation between internships and school enterprises are emphasized, and it can be seen that if the internship is assigned by the school arrangement, there is usually no salary. If the students themselves are looking for internships outside the school, it is possible to pay wages, but the remuneration will not be too high [9].

Work-making refers to the social practice of improving living conditions by using their spare time and obtaining labor remuneration through labor under the organization of the school [10].

In most cases, similar to drip taxis or platform writing methods are results-oriented payment model. Even online teaching or other brain-paying work patterns are more difficult to simply measure in unit time, using only time units for pay calculations, which is clearly unfair to college students who use a lot of mental work. Therefore, the problem of college students ' gig economy wages can only be resolved by civil law, but because the civil law is quite cumbersome and complex in procedure, Time is also longer, so when college students expect to solve pay labor disputes through formal channels, they may be in a dilemma. 


\section{REASONS FOR INFRINGEMENT OF ECONOMIC LABOR RIGHTS AND INTERESTS OF COLLEGE STUDENTS ' GIG ECONOMY JOBS}

\section{A. Firstly, Imperfect In The Relevant Labor Laws}

China's current labor law is mainly aimed at the traditional labor relations, no longer applicable to the new characteristics of labor relations.

At present, the most prominent point is that the definition criteria of labor relations are not clear, and the ambiguity of labor relations identification standards gives many network sharing platforms the opportunity to "drill holes" in labor contracts. Under the gig economy-wage economic employment model, the employment relationship becomes more flexible and elastic, and flexible employment has become a trend. At present, the current labor law, the labor contract laws are mainly aimed at the traditional typical labor relations, and the existing domestic laws are difficult to protect the legal labor rights and interests of college students. In fact, when a college student provides mental services to an independent employer, such as teaching the professional knowledge of the relevant field to the individual through the network platform, the labor dispute that occurs applies to the civil law, and the dispute should be settled through equal consultation.

\section{B. Secondly, Loopholes in the Supervision of Network Sharing Platform}

There is no doubt that the rapid development of the gig economy is based on the rapid progress of network information technology. But the negative consequence of the rapid development of network sharing platform is that the corresponding law enforcement efforts cannot fully cover the legal gap derived from the development of the platform. The new employment mode under the gig economy through the platform management, with the help of capital to remove the intermediate way in the employment process, the equivalent of a de-intermediation and re-intermediary process. But in this process there will be a suspicion that enterprises deliberately avoid legal constraints. Take advantage of regulatory gaps in law enforcement to obtain intermediate benefits. And once enterprises through the network platform to form an internet monopoly, workers will become no choice, it is easy to form a labor exploitation [11].

The second is that when labor disputes arise, the handling of problems can become complicated. Mainly reflected in the complexity of the subject of the dispute and the complexity of the dispute process. the extension of the network sharing platform makes the labor subject may involve the relationship between the three parties or the Quartet, so that the employment risk of the enterprise can be minimized, However, when employees defend their rights, they will face the dilemma of not knowing which side the responsibility belongs to, thus making it more difficult to protect rights.

\section{Thirdly, College Students 'Awareness Of Their Own Rights Needs To Be Improved}

Many college students in the choice of gig economy work activities only focus on pay and time issues, which gives some of the ill-intentioned enterprises can take advantage of the machine. And many college students through some mobile terminals or platforms to find gig economy jobs, usually do not sign a written contract, even if a small number of college students and employers signed a written contract or agreement, but the contents of the regulations involved are very simple, for labor safety protection, injury compensation and other issues are rarely mentioned.

\section{Fourthly, Inadequate Management of Schools}

The Employment Guidance Center for college students is mainly for the graduating college students to carry out career planning and job search guidance set up institutions, and most college students employment guidance classes are only a form. School this aspect of the knowledge publicity is not enough, resulting in college students related to the legal knowledge of the reserve is not enough, in the event of disputes also do not know how to deal with.

\section{COUnTERmeasures To StREngthen The Rights AND INTERESTS OF COLLEGE STUDENTS}

\section{A. Firstly, improve the insurance system for college students}

To clarify the social security system of college students ' gig economy-made groups. China's traditional Trinity Social security system has been difficult to meet the flexible and diversified employment model, so that workers directly participate in the social security model rather than the enterprise as the main social security model.

In addition, because college students still belong to the learning stage, not out of school, so the general social Security in society is not applicable to college students. Then from the employer's point of view, we should strengthen security measures and purchase related commercial insurance, so as to better protect the rights and interests of college students. Because commercial insurance is mainly when college students encounter unexpected events in the course of gig economy jobs, to the school students a certain degree of financial compensation insurance, can better for the security rights and interests of the school students to provide financial assistance. There are many differences between commercial insurance and social insurance, but in essence it is to provide security for the public. There is no strict target range limit for commercial insurance, and whether or not to choose to be insured is entirely in the freedom of the public, which makes up for the shortcoming that social insurance can only cover a part of the social citizens. Therefore, college students who are not covered by social insurance can reduce their losses through commercial insurance and improve their ability to resist risks [12]. 


\section{B. Secondly, strengthen the supervision system of network platform}

Because of the relationship between laborers and platforms, the relationship between enterprises and platforms, the relationship between enterprises and laborers cannot be determined simply by the traditional labor law theory. The Government should strengthen the supervision of the network platform, and review and control the recruitment information issued by the network platform. The platform itself should strengthen self-regulation and create a green and safe network environment for job seekers. [13]

\section{Thirdly, establish college students casual rights and Interests Protection Association, and form third-party power}

In the current comprehensive rules and regulations have not been perfected, in order to try to meet the needs of college students, schools or the community can set up some trade unions or related organizations, so that even if there is a labor dispute, college students will not feel that their strength is too thin, isolated, and collective forces can be used to seek help in solving difficult situations.

It is extremely urgent to set up a labor union to protect the rights and interests of college students. Its main goal is to fully protect the legal rights and interests of college students working as part-time workers, enable the labor union to speak for college students, and let the labor union represent college students to express demands and safeguard rights and interests. In this way, the trade union can play an active role in safeguarding the rights and interests of college students and become an important driving force for the protection of the rights and interests of college students [14].

\section{CONCLUSION}

To sum up, on the one hand, the gig economy breaks the limitations brought by the traditional employment model, improves the flexibility of the employment market and gives more college students the opportunity to work flexibly. On the other hand, there are still many deficiencies in the protection of the rights and interests of college students, including the protection of labor security rights and interests of college students, social welfare rights and interests as well as the protection of salary rights and interests. So this would require the relevant departments as soon as possible to improve labor law so as to adapt to the new employment mode, perfect the system of college students in the gig economy jobs and economic insurance, but also to strengthen the supervision of the network platform, the society should also establish college students' rights and interests protection association, promote the third party strength for college students to speak, and, more importantly, also must strengthen the legal consciousness of college students themselves. Only in this way can we improve the new mechanism of employment market, better ensure the legitimate rights and interests of college students in the wave of gig economy, and provide strong support for college students as innovative talents to play their positive role in the employment market.

\section{ACKNOWLEDGEMENT}

This research was financially supported by National social science fund education general project

"entrepreneurial law education research based on risk control in science and Engineering University", No. BIA170192.

This research was financially supported by the project of innovative and entrepreneurial training program for provincial university students in Hubei in 2017: Study on the influence on their employment and Entrepreneurship of the college students' participation in the zero work economy, NO: 201710488037

\section{REFERENCES}

[1] China shares annual report on economic development,2018:10. (In Chinese)

[2] Zhang chunmei, li mengtian, jia shuwen, et al. Investigation and research on college students' part-time employment tendency -- a case study of undergraduate universities in xiaogan area [J]. Modern business and trade industry, 2018(16):76. (In Chinese)

[3] Qiu shuping. On the inspiration of Internet crowdsourcing on the innovation of modern enterprise management mode $[\mathrm{J}]$. Contemporary economy, 2018(12):100-101. (In Chinese)

[4] Opinions on the implementation of the labor law of the People's Republic of China issued by the ministry of Labour,1995:309. (In Chinese)

[5] Wang xiaohong. The application of part-time personal injury and labor law for university students [J]. Journal of jiangsu vocational and technical college of economics and trade,2017(1):51-54. (In Chinese)

[6] Opinion of the ministry of Labour and social security on a number of issues concerning part-time employment,2003:12 (In Chinese)

[7] Wu huijun. "gig economy" calls for flexible social security [J]. Sunset glow, 2018(6):1-2. (In Chinese)

[8] Lin Juan. From the perspective of labor law, college students' part-time "salary" [J]. Journal of political science and law,2013, 30(4):52-58. (In Chinese)

[9] Several opinions on comprehensively improving the teaching quality of education in higher vocational education,2006:16 (In Chinese)

[10] Administrative measures on work-study in colleges and universities, 2007:7 (In Chinese)

[11] Yuan wenquan, xu xinpeng. Legal regulation of concealed employment relationship from the perspective of sharing economy [J]. Political law BBS,2018(1):119-130. (In Chinese)

[12] Zhang yingqin. On the complementarity between commercial insurance and social insurance [J]. Theory guide, 2000(3):36-37. (In Chinese)

[13] Jiang daxing, wang shoujie. Legal regulation of sharing economy [J]. Chinese social science,2017(9):141-162. (In Chinese)

[14] Li xiahe. Promoting the protection of trade unions in universities by rule of law thinking and rule of law $[\mathrm{J}]$. Journal of shenyang jianzhu university (social science edition), 2015(1):94-98. (In Chinese) 